\title{
EFFORTS, SUCCESSES AND CHALLENGES OF GREEN FEED PRODUCTION IN ETHIOPIA
}

\author{
Getachew ASSEFA WOLDEMARIAM $\approx$ \\ College of Veterinary Medicine and Animal Sciences, Department of Animal Production and Extension, University of Gondar P.O.Box 196, Ethiopia \\ ${ }^{凶}$ Email: gawgetachew2@gmail.com; (D)RCiD: 0000-0002-0593-0739 \\ Supporting Information
}

\begin{abstract}
Improving the feed supply and digestibility of roughage through green feed supplementation was the aim of forage production in Ethiopia. In spite of the time-consumed efforts made, the success is still low. This review summarizes efforts, challenges, good practices and indicates where the focus of future efforts should be. The efforts made in improve forage production (IFP) includes selection of forage species and development strategies, preparation of extension manual, training of stakeholders, formulation of forage seed production system, and introduction of hydroponic fodder. As a result farmers increased milk production and reduce feed cost by $20 \%$ and $40 \%$, respectively, and fatten ruminants in 2 to 3 cycles per year as a result of improved forage use. However, there is no management model for communal grazing land. IFP constrained by long dry period, scarcity of land, irrigation and the subsistence system of livestock production and the free grazing practice. Consequently, the communal grazing lands are devastatingly overstocked and degraded, livestock become dependent on crop residues, IFP practice remains low and livestock feed deficit is common. Therefore, it is recommended that future efforts should focus on designing communal grazing land tenure model and development package. Green forge production (GFP) should concentrate on livestock excluded areas and tree legumes to produce green feed in the dry period. GFP best practices should be expanded to the areas similar to that the practices found effective. Reduce feed deficit by improving crop production to increase the crop residue and the grain yield. The subsistence system of production should be transformed into market-oriented by introducing a technology package that reduces young stock mortality, increases fertility, calf/ lamb crop and livestock offtake rate. Technical simplicity and cost-effectiveness, of the hydroponic fodder system, should be assessed before implemented in a wider setting.
\end{abstract}

Keywords: Animal Nutrition, Forage, Grazing, Green feed, Livestock.

\section{INTRODUCTION}

Improved forage production started in Ethiopia in 1950s (Fikre, 2018). In spite of its long history and existence of some exemplary practices, the contribution of improved forage to the total feed resource is still low (0.32 \%; CSA, 2018). The communal grazing lands are ownerless and devastatingly overstocked and degraded due to the absence of a clear model that indicates the right and obligation of users. Livestock become increasingly dependent on crop residues (Stark et al., 2018; Atsbha et al., 2020). Feed supply deficit is common in the mixed crop-livestock production system of Ethiopia.

The objective of improved forage production in Ethiopia was to increase feed supply and improve the intake and digestibility of the poor quality hay and the crop residues through green feed supplementation. The net digestibility of dry forages can be increased when fed together with $25 \%$ of fresh green material (Horrocks and Vallentine, 1994). The total digestibility of dry matter increased when 10 to $30 \%$ of the concentrated portion of the ration replaced by green feed in the form of hydroponic fodder (AL-Saadi et al., 2015).

Young, dark green forage tends to contain more minerals than old, dry, yellowing forage (Lukuyu et al., 2007). They also contain vitamins or raw material for vitamin synthesis in the rumen. Green fodders are good sources of $\alpha$-tocopherol (the most biologically active form of vitamin E), young grass being a better source than mature herbage. The leaves contain 20-30 times as much vitamin E as the stems (McDonald et al., 2007). Losses during haymaking can be as high as 90 percent, but losses during ensilage or artificial drying are low (McDonald et al., 2007). Silage and hay contain 20 to 80 percent less $\alpha$-tocopherol than does fresh forage (NRC, 2001).

Vitamin $\mathrm{E}$ involves in the maintenance of cellular membranes, immunity, and reproductive function. White muscle disease is a classic sign of a clinical deficiency of vitamin E (NRC, 2001). Vitamin E deficiency also found to have a relationship with mastitis, and immune function (NRC, 2001). Green herbage is also an exceptionally rich source of $\beta$ carotene, a precursor of vitamin A, and the dry matter of the young green crop may contain as much as $550 \mathrm{mg} / \mathrm{kg}$ (McDonald et al., 2007). Vitamin A is necessary for low light vision, normal growth and development (including fetal growth), spermatogenesis, and for maintenance of skeletal tissue and epithelial tissue (NRC, 2001). Abortions, increased prevalence of retained fetal membranes, and increased calf morbidity and mortality are indicators of vitamin A deficiency in gestating cows (NRC, 2001). 
Green feeds also provide vitamin $K$ to animals (McDonald et al., 2007). Cattle require vitamin $K$ for the synthesis of at least a dozen proteins; among these are four blood clotting factors; prothrombin (factor II), and factors VII, IX, and X (NRC, 2001). These vitamin $\mathrm{K}$ dependent protein factors are components of a complex system that functions to prevent hemorrhage by activation of thrombin and ultimately clot formation (NRC, 2001). Green feed reduces Methane emission to the environment (Prusty et al. 2014; Mohini et al., 2007). The enteric methane emission was reduced by 5-12\% on feeding green fodder based ration to river buffaloes (Prusty et al. 2014). Mohini et al. (2007), reported lower CH4 emission (218.15 vs. 233.50 and $252.82 \mathrm{~g} / \mathrm{d}$ ) in lactating cows fed only fresh green fodder and concentrate mixture as compared to dry roughage fed cows. The inhibition of hydrogen-producing bacteria that are accounted for the metabolization of pyruvate to acetyl CoA might also be responsible for the reduction of methane emission on feeding green fodder (Hossain et al., 2017). Nathani et al., (2015) also reported that increasing green fodder proportion in the diet might have also reduced the active genes for the production of methane by reducing the methanogenic archaea population in the rumen. Dairy animals producing up to 5-7 liters of milk per day can be maintained exclusively by feeding green fodders (Hossain et al., 2017).

To increase green feed supplementation practices, immense efforts have been made in selecting and introduction of different forage species in different agro-ecological zones of Ethiopia (Alemayehu, 2006). However, apart from some exemplary achievements observed, the practical use of improved forage crops for animals is still low in many areas (Mekoya, 2008). The objective of this review is to summarize the efforts, challenges, and available good practices in green feed or forage production and indicate where the future efforts should focus.

\section{DISCUSSION}

\section{Efforts of green forage production in Ethiopia}

Forage development for livestock has a long history in Ethiopia going back to the 1950s at Jimma and moving on through activities at Haramaya University (Fikre, 2018). The forage and pasture seed production began in 1970 in Ethiopia by Arsi Rural Development Unit (ARDU/ CADU) (Alemu, 2011; Mengistu and Assefa, 2012). Oats, vetch, Rhodes grass, Phalaris, Panicum, Buffelgrass, Elephant grass, Green leaf desmodium and Fodder beet were produced in Kulumsa, Dera, Bekoji, Assela and other livestock farms (Fikre, 2018).

The contractual system of forage seed production was initiated by the Fourth Livestock Development Project (FLDP) in 1987/88 on the objective of producing better quality seed at lower prices and greater quantities in centrally controlled seed production systems using individual farmers and farmers cooperatives (Fikre, 2018). The program placed emphasis on the production of forage legume seed, with a capacity of 100-120 tons of forage seed per year during its period of operation (Grass and Turner, 1997, Alemayehu et al., 1994). The contractual forage seed development system functioned well during the project lifespan, but after the project phased out, seed production-related activities failed to operate as successfully as they did during FLDP (Fikre, 2018). The forage seed production intervention was continued by Smallholder Dairy Development Program (SDDP) from 1987-1991 in Heifer distribution together with forage/seed (Yimer and Kidane, 2015).

Various improved forage production strategies were developed and implemented. The strategies evolved from experiences of other countries and an understanding of the importance of matching forage systems to different agroecological zones of Ethiopia (Alemayehu et al., 2017). Almost all the strategies emphasize the cut and carry system of feeding, on the objective of providing succulent green forage thereby maintaining the health of soil conservation structures on which the forage planted.

The strategies have presented in the forage extension manual of FLDP. In addition to the strategies, the manual contains the basic guidelines for forage development and management at the farm level. The manual is written for Development Agents in the ministry of agriculture but is useful for all extension workers (FLDP, 1989). The commercial green feed has been produced by YB Plant Micropropagation PLC owned by Behaylu Abraha in the low-cost hydroponic fodder production system in 2014 in Ethiopia. The number of dairy farm owners relying on Behaylu for hydroponically produced barley fodder has grown steadily, reaching 400 milking cows (LIVES, 2014). Hydroponics fodder is a succulent fodder without soil but in water or nutrient-rich solution in a greenhouse (hi-tech or low-cost devices) for a short duration, 7 to 10 days (Naik et al., 2015).

Since a couple of decades ago, hydroponic fodder production technology has been advocated as a solution for conventional green fodder production challenges and as a climate change adaptation strategy (Muthuramalingam et al., 2015) in many countries. On the contrary, other groups of authors argue that the profitable use of sprouting grain as a feed source for commercial cattle production appears unlikely (Sneath and McIntosh, 2003) or totally have no advantage (Fazaeli et al., 2012). The major reason for tending to discourage hydroponic fodder production by these groups includes reduction in dry matter (DM) weight and greater cost as a result of sprouting. Nevertheless, some other authors noted that it is the ultimate animal performance relative to the alternative costs that determine the profitability and usefulness of hydroponic fodder (Tranel, 2013), which indicates that the usefulness of hydroponic fodder depends on local condition. Although such dialogue exists among professionals, hydroponic fodder production technology was introduced to some parts of Ethiopia without any preliminary study. 


\section{Successes of forage production in Ethiopia}

In the area, where market for forage or animal products available improved forage production practice is suitable. A study made by Mesfin et al. (2013a,b) in such area namely Girar Jarso, Tiyo, chiro district farmer allocate $400 \mathrm{~m}^{2}$ to one hectare per household for forage production. Farmers reported that the improved forage used in feeding dairy and fattening animals increased their income, reduced their feed cost due to the decrease in concentrate cost and ensured the year-round feed availability. Good animal management practice reduced the disease problem during animal breeding. According to the interviewed farmer, milk production may increase by about $20 \%$ while feed cost reduced by about $40 \%$ (Mesfin et al., 2013a). In the irrigated sites, farmers have been able to harvest elephant grass forage year-round, usually at monthly or bi-monthly intervals. Due to the year-round fodder availability, farmers are able to fatten cattle and/or small ruminants 2 to 3 cycles per year and milk yield of local cows increased from 1 to 3 liters/cow/day (Mesfin et al., 2013b). Moreover, elephant grass planted along the edges of irrigation canals have also improved the feed availability particularly during the dry period and help in stabilizing the irrigation canal thereby reducing water loss through evaporation (Mesfin et al., 2013b). Additional income obtained from the sale of planting materials of elephant grass was another benefit, even though such benefit is rarely obtained but its future potential market looks promising (Mesfin et al., 2013b).

\section{Challenges of forage production in Ethiopia}

Even if exemplary improved forage production practices found in some pocket areas of Ethiopia, the contribution of improved forgeries to the total feed resources is still very small. According to CSA (2018) improved forage production covers only $\mathbf{0 . 3 2} \%$ of the total feed resources of livestock in rural peasant farmers of Ethiopia. The failures of green feed production in many places are due to scarcity of land and water for irrigation. In the highland of Ethiopia, where mixed crop-livestock production system exists, farmers give priority in allocating land more often to crops than forage production. There is no market-oriented livestock production in most of the mixed crop-livestock production systems. Cattle are primarily kept to supply draft power needed for crop production (FAO, 2018). Small ruminants are maintained as a means of savings and meat for household consumption (Gizaw et al., 2010). Inadequate feed supply is one of the major constraints hampering market-oriented livestock development in Ethiopia (Firew and Getnet, 2010).

In Ethiopia, most farmers practice free grazing except in areas, such as Harerghe, where grazing lands are limited in size and where the farming system favors the growth of perennial cash crops (Gebregziabher and Gebrehiwot, 2011). Damage of improved forages planted by some farmers with the animals of the others due to the open grazing system practice is one of the reasons for the low adoption of forage development in many areas of Ethiopia. Efforts made to introduce zero (controlled) grazing in 2006. The strategy was to adopt what Hararghe farmers have been practicing for years. However, this has been faced by resistance by farmers which has resulted in a low adoption rate. Farmers relate zero-grazing with grazing land confiscation (Gebregziabher and Gebrehiwot, 2011).

The increasing expansion of land cultivation for crop production (Amsalu et al., 2007; Bogale et al., 2008) and construction of public institutions at the expense of grazing land has resulted in shrinkage of the area. Grazing lands are devastatingly overstocked and that the herbage biomass productivity is declining both in quantity and quality (Hassen et al., 2010; Tschopp et al., 2010; Alemayehu, 2013). In general, crop residues are increasingly becoming the main sources of livestock feed resources in the mixed crop-livestock production systems (Bogale et al., 2008; Duncan et al., 2016).

Overall, about 51, 19 and 38\% annual feed deficit in DM, ME and DCP, respectively were reported in the central high land of Ethiopia (Mekete et al., 2018). Feed supply deficits in mixed crop-livestock production system have also reported by Kassa et al. (2003) and Wondatir et al. (2011), in Gummara-Rib watershed of the Lake Tana in Amhara region, and Harerge highland, respectively. In most parts of Ethiopia, the livestock management practice is a low-input, low-output traditional extensive system. During the FLDP life, the price of forage seed was not governed by the free market. The project purchase with higher price from seed producer farmers and supply to the forage producers free of charge or with a highly subsidized price. When the project phase-out efforts of promoting forage seed production and dissemination did not sustain as the agricultural offices did not have sufficient grant money to purchase and supply seed. Forage seed production also ceased because farmers chose to use their land to produce other types of seed and crops that had a more significant impact on their livelihoods (Tekalign, 2014). This faded the glimmered hop of green feed production in conventional feed production in Ethiopia.

\section{CONCLUSION AND RECOMMENDATION}

It is concluded that the absence of a clear model for use right and development obligation makes the communal grazing land ownerless and devastatingly overstocked and degraded. Even there are some exemplary practices, the long dry period, absence of irrigation and land scarcity coupled with low input low output subsistence system of livestock production put the improved forage production difficult in rural Ethiopia. Therefore it is recommended that future efforts should focus on selecting, testing and implementing a communal tenure model that is suitable to communal grazing lands in Ethiopia and improve the productivity of grazing lands by over-sowing, differed grazing and controlling stocking rate as per the caring capacity of the grazing lands. Improved green feed/forage production should concentrate on livestock excluded areas. Emphasis should be given to tree legumes to produce green feed in the dry period to be used by a cut and carry system. 
Green feed production best practices should be expanded to the areas similar to that the practices found effective. Organize farmers' visit and open discussion among farmers. Reduce feed deficit by increasing livestock off-take during a time of scarcity and multidimensional crop improvement to increase the quantity and feeding value of crop residue without negatively affecting the grain yield. Finally, gradually transform the low-input low output livestock production to the market-oriented system by formulating and introducing a multidisciplinary livestock technology package that reduces young stock mortality, increases fertility that increases the calf/ lamb or kin crop to be sold and finished in urban and peri-urban areas where better agro-industrial byproducts available. The compatibility of hydroponic fodder to the local conditions including its technical simplicity, cost-effectiveness, and performance of locally available seeds in the hydroponic system should be assessed before expanding the technology throughout the country.

\section{DECLARATIONS}

\section{Corresponding author's E-mail: gawgetachew2@gmail.com}

\section{Authors' contribution}

The author contributed alone to this work starting from reviewing publishes articles to preparation of the manuscript.

\section{Acknowledgements}

The author would like to thank the University of Gondar for providing us comfortable working environment including uninterrupted electricity and internet service for our office which were the main imputes for this work.

\section{Conflict of interests}

The author declare that there is no conflict of interests on this work

\section{REFERENCES}

Alemayehu M (1994). Forage seed production systems in Ethiopia. InILCA/ICARDA Research Planning Workshop on Seed Production by Smallholder Farmers, Addis Ababa (Ethiopia), 13-15 Jun 1994. ILCA. Google Scholar

Alemayehu M (2006). Country Pasture/Forage Resource Profiles, Ethiopia. FAO, Rome. https://www.scribd.com/document/346403139/FAO-Forage-Profile-Ethiopia

Alemayehu M, Kebede G, Feyissa F and Assefa G (2017). Overview of improved forage and forage seed production in Ethiopia: Lessons from Fourth Livestock Development Project. International Journal of Agriculture and Biosciences, 6(4): 217-226. https://www.cabdirect.org/cabdirect/abstract/20183073957

Alemayehu M. (2013). Livestock-water interactions: the case of Gumara watershed in the Upper Blue Nile Basin, Ethiopia. Ph.D. Thesis, Der Humboldt Universität Zu Berlin, Berlin, p.1-141. http://publication.eiar.gov.et:8080/xmlui/handle/123456789/397?show=full Google Scholar

Alemu D (2011). Farmer-Based Seed Multiplication in the Ethiopian Seed System: Approaches, Priorities, and Performance. Future Agricultures Consortium, Version: Working Paper no 36. https://opendocs.ids.ac.uk/opendocs/handle/20.500.12413/2252 I Google Scholar

AL-Saadi MJ.and Al-Zubiadi IAH (2015). Effects of substitution barley by $10 \%, 30 \%$ of sprouted barley on rumen characters, digestibility and feed efficiency in diet of awassi male lambs. International Journal of Science and Research, 5: 2319-7064. Google Scholar I https://www.ijsr.net/get_abstract.php?paper_id=NOV163174

Amsalu A, Stroosnijder L, Graaff JD (2007). Long-term dynamics in land resource use and the driving forces in the Beressa watershed, highlands of Ethiopia. Journal of Environmental Management, 83(4):448-59. https://doi.org/10.1016/j.jenvman.2006.04.010 Google Scholar

Atsbha T, Wayu S, Gebretsadkan N, Giday T, Gebremariam T (2020). Exclosure land management for restoration of herbaceous species in degraded communal grazing lands in Southern Tigray. Ecosystem Health and Sustainability. 6(1): 1829993. D0I: https://doi.org/10.1080/20964129.2020.1829993 I Google Scholar

Bogale S, Melaku S, Yami A (2008). Potential use of crop residues as livestock feed resources under smallholder farmers conditions in Bale highlands of Ethiopia. Tropical and Subtropical Agroecosystems, 8: 107-114. Link I Google Scholar

CSA (Central Statistical Authority) (2018). Livestock and Livestock Characteristics (Private Peasant Holdings). Agricultural Sample Survey 2017/18, 2010 E.C. http://www.csa.gov.et/atlas/category/61-livestock-agricultural-sample-survey

Duncan AJ, Bachewe F, Mekonnen K, Valbuena D, Rachier G, Lule D, Bahtaf M. and Erensteing 0 (2016). Crop residue allocation to livestock feed, soil improvement and other uses along a productivity gradient in Eastern Africa. Agriculture, Ecosystems and Environment, 228: 101-110. https://doi.org/10.1016/j.agee.2016.05.011 I Google Scholar

FAO (2018). Africa sustainable livestock (2050). Livestock production systems spotlight Ethiopia cattle sectors, FAO, Rome. http://www.fao.org/3/I8271EN/i8271en.pdf I Google Scholar

Fazaeli H, Golmohammadi HA, Tabatabayee SN and Asghari-Tabrizi M (2012). Productivity and nutritive value of barley green fodder yield in hydroponic system. World Applied Sciences Journal, 16 (4): 531-539. https://www.idosi.org/wasj/wasj16(4)12/9.pdf I Google Scholar

Fikre H (2018). Efforts being made and success achieved in producing improved seed of forage cops in Ethiopia. Advances in Crop Science and Technology, 6: 343. Link I Google Scholar

Firew TA and Getnet A. (2010). Feed Resources Assessment in Amhara Regional State, Ethiopia Sanitary \& Phyto-sanitary Standards and Livestock \& Meat Marketing Program (SPS-LMM), Adiss Ababa. Google Scholar

FLDP (Fourth Livestock Development Project) (1989). Forage extension manual. Ministry of Agriculture, Animal and Fisheries Resources Development Main Department; Addis Ababa, Ethiopia.

Gizaw S. (2010). Sheep and goat production and marketing systems in Ethiopia: Characteristics and strategies for improvement. ILRI (aka ILCA and ILRAD); 2010. I Google Scholar 
Grass L, and Turner M (1997) Pasture and forage seed production. In Africa and West Asia proceedings of the pasture and forage seed production workshop, Addis Ababa, Ethiopia. International Centre for Agricultural Research in the Dry Areas (ICARDA), pp: 203. Link I Google Scholar

Hassen A, Ebro A, Kurtu M, and Treydte AC (2010). Livestock feed resources utilization and management as influenced by altitude in the Central Highlands of Ethiopia. Livestock Research for Rural Development, 22, Article 22(229). http://www.Irrd.org/Irrd22/12/hass22229.htm I Google Scholar

Horrocks RD, and Vallentine JF (1999). Forages and animal nutrition: the basics. Editor(s): RD. Horrocks, and JF. Vallentine: Harvested Forages, Academic Press, USA, Pp. 59-74. https://doi.org/10.1016/B978-012356255-5/50026-2 I Google Scholar

Hossain SA, Sherasia PL, Phondba BT, Pathan FK and Garg MR (2017). Effect of feeding green fodder based diet in lactating buffaloes: Milk production, economics, and methane emission. Indian Journal of Dairy Science, 70(6):767-773. http://epubs.icar.org.in/ejournal/index.php/IJDS/article/view/70997/31991 I Google Scholar

Kassa H, Gibbon D, Tamir B (2003). Use of livestock feed balance as a potential indicator of sustainability of tropical smallholder mixed farms-prevailing knowledge gaps: a case study from the Harar highlands of eastern Ethiopia. Journal of Sustainable Agriculture, 22: 37-41. https://doi.org/10.1300/J064v22n04_04 I Google Scholar

LIVES (livestock and Irrigation Value Chain) (2014). Hydroponic fodder production for smallholder livestock farmers. https://livesethiopia.org/2014/04/29/hydroponic-fodder/

Lukuyu M, Romney D, Ouma R, and Sones K (2007). Feeding dairy cattle. A manual for smallholder dairy farmers and extension workers in East Africa. ILRI Manuals and Guides. no. 2. 51p. Nairobi (Kenya): ILRI. https://cgspace.cgiar.org/handle/10568/478 I Google Scholar

McDonald P, Edwards RA, Greenhalgh JFD, Morgan CA, Sinclair A, and Wilkinson R (2007). Animal Nutrition. $7^{\text {th }}$ ed. ISBN13:9781408204238. Trans-Atlantic Press, UK. Google Scholar

Mekete BT, Ashenaf MW and Berhan TM (2018). Evaluation of livestock feed balance under mixed crop-livestock production system in the central highlands of Ethiopia. Agriculture and Food Security, 7:19. https://doi.org/10.1186/s40066-018-0170-8 I Google Scholar

Mekoya A (2008). Multipurpose fodder trees in Ethiopia: Farmers' perception, constraints to adoption and effects of long-term supplementation on sheep performance, Doctorial Dissertation, Wageningen University, Wageningen https://edepot.wur.nl/121948 I Google Scholar

Mengistu A, Assefa G (2012) The Evolution of Forage Seed Production in Ethiopia. In: Assefa G (eds.) Forage Seed Research and Development in Ethiopia. Proceedings of a workshop organized by EIAR-ASARECA Cooperation, Ethiopian Institute of Agricultural Research, Addis Ababa, Ethiopia. Google Scholar

Mesfin D, Ashebir T, Getnct A, Acmiro K, and Ameha S (2013a). Fodder Production, Utilization and Marketing Practices in Mixed CropLivestock Production Systems of the Highlands of Ethiopia. pp. 1-18. In Getnet Assefa, Biruk Hailu Emmanuelle Guerne Bleich and Alemayehu Mengistu (Ed). Proceeding of Best Practices in Feed Resources Production, Management and Utilization Sub-regional Experience Sharing Workshop $3^{\text {rd }} 6^{\text {th }}$ December 2013, EIAR, Addis Ababa, Ethiopia. Google Schola

Mesfin D, Ashebir T, Getnct A, Acmiro K, and Ameha S (2013b). Fodder Production, Utilization and Marketing Practices in Mixed CropLivestock Production Systems in the Mid Altitude Areas of Ethiopia. pp. 67-84. In Getnet Assefa, Biruk Hailu Emmanuelle Guerne Bleich and Alemayehu Mengistu (Ed). Proceeding of Best Practices in Feed Resources Production, Management and Utilization Subregional Experience Sharing Workshop $3^{\text {rd }} 6^{\text {th }}$ December 2013, EIAR, Addis Ababa, Ethiopia. Google Scholar

Mohini M, Mani V, Singh GP (2007) Effect of different ratios of green and dry roughage on milk production and methane emission in cattle. Indian Journal of Animal Science, 77(1): 79-82. https://nrcy.icar.gov.in/research.htm I Google Scholar

Muthuramalingam T, Pothiappan P, Gnanaraj PT, Sundaram SM, and Pugazhenthi TR (2015). Studies on growth performance of the goats fed hydroponic maize fodder. Indian Veterinary Journal, 92(4): 94-96. I Google Scholar

Naik PK, Swain BK, and Singh NP (2015). Production and utilisation of hydroponics fodder. Indian Journal of Animal Nutrition, 32 (1): 1-9. https://www.indianjournals.com/ijor.aspx?target=ijor:ijan\&volume=32\&issue=1\&article=001 I Google Scholar

Nathani NM, Patel AK, Mootapally CS, Reddy B, Shah SV, Lunagaria PM, Kothari RK, and Joshi CG (2015). Effect of roughage on rumen microbiota composition in the efficient feed converter and sturdy Indian Jaffrabadi buffalo (Bubalus bubalis). BMC Genomics, 16:1116. DOI: https://doi.org/10.1186/s12864-015-2340-4 I Google Scholar

NRC (National Research Council of the United States) (2001). Nutrient requirements of dairy cattle. $7^{\text {th }}$ Revised Edition, Subcommittee on Dairy Cattle Nutrition, Committee on Animal Nutrition, Board on Agriculture and Natural Resources, National Research Council, National Academy Press, Washington, D.C. Google Scholar

Prusty S, Mohini M, Kundu SS, Kumar A, Datt C (2014). Methane emissions from river buffaloes fed on green fodders in relation to the nutrient intake and digestibility. Tropical Animal Health and Production, 46(1): 65-70. https://doi.org/10.1007/s11250-013-0447-7 I Google Scholar

Sneath R and McIntosh F (2003). Review of hydroponic fodder production for beef cattle. Report prepared Meat \& Livestock Australia Limited. QueensI and Government, Department of Primary Industries, Australia. ISBN 1740365038. https://www.mla.com.au/contentassets/fe41462b573d4125a823e01a56572dad/nbp.332_final_report.pdf I Google Scholar

Stark F, González-García E, Navegantes L, Miranda T, Poccard-Chapuis R, Archimède H, and Moulin C (2017). Crop-livestock integration determines the agroecological performance of mixed farming systems in Latino-Caribbean farms. Agronomy for Sustainable Development, 38: 1-11. https://doi.org/10.1007/s13593-017-0479-x I Google Scholar

Tekalign E (2014) Forage seed systems in Ethiopia: A scoping study. ILRI Project Report. International Livestock Research Institute (ILRI) Nairobi, Kenya. https://cgspace.cgiar.org/bitstream/handle/10568/65142/PR_forage_seed\%20_ethiopia.pdf?sequence=1 Google Scholar

Tranel LF (2013). Hydroponic Fodder Systems for Dairy Cattle. Animal Industry Report: AS 659, ASL R2791. http://lib.dr.iastate.edu/ans_air/vol659/iss1/42 I Google Scholar

Tschopp R, Asefa A, Schelling E, Zinsstag J (2010). Farmers' perceptions of livestock, agriculture, and natural resources in the rural Ethiopian highlands. Mountain Research and Development, 4: 381-390. https://doi.org/10.1659/MRD-JOURNAL-D-09-00072.1 Google Scholar

Wondatir Z, Mekasha Y, Wouters B. (2011). Assessment of productive and reproductive performance of dairy cattle nexus with feed availability in selected peri-urban areas of Ethiopia. Journal of Cell and Animal Biology, 5(15): 308-315. https://doi.org/10.5897/JCAB.9000022 I Google Scholar

Yimer E, and Kidane T (2015). National consultation workshop on forage and forage-seed industry development for improved livestock production and productivity. Workshop Proceedings, Addis Ababa, Ethiopia. Google Scholar 